\title{
New Approaches to Studying Information Technology: Escaping the Organizational Straightjacket
}

\author{
Nik R. Hassan \\ University of Minnesota Duluth, Duluth, MN, USA
}

nhassan@d.umn.edu

\begin{abstract}
The information systems (IS) field has been constrained by organizational studies (OS) for far too long. Although the close relationship between IS and OS has produced fruitful results, the prevalence of IT and its ever-widening impact at all levels of society requires that the IS field escape its organizational straightjacket and embrace new foundations. This research presents a foundation for new approaches towards studying IT that not only recognizes the critical role that technology plays, but also recognizes how information in IT brings new meaning into society.
\end{abstract}

Keywords: Information systems field, IS theory, technoscience, philosophy of information technology, reference disciplines, organization studies.

\section{Introduction}

The information systems (IS) field has historically limited itself to the design, use and implementation of information technology (IT) in organizations. Consequently, it is no surprise that the IS field has become constrained by this "organizational straitjacket" since its inception. Dickson (1981, p. 20) acknowledges that "much of the [management information systems] MIS research that has been performed has been done in an organizational setting." Markus (1999) was the first to highlight the tendency of the field to be constrained by its roots in organizational science. The IS field, she warns, is at a crossroads and in order to avoid possible extinction, needs to go beyond its traditional areas of study by revisiting its mission and its customers. Markus notes that the core concerns of the IS field are no longer limited to the needs of the IS department and the organization that it serves. IT is so prevalent today that its benefits and dangers are felt beyond organizational or disciplinary boundaries. Galliers (2003) emphasizes the need for a trans-

Material published as part of this publication, either on-line or in print, is copyrighted by the Informing Science Institute. Permission to make digital or paper copy of part or all of these works for personal or classroom use is granted without fee provided that the copies are not made or distributed for profit or commercial advantage AND that copies 1) bear this notice in full and 2) give the full citation on the first page. It is permissible to abstract these works so long as credit is given. To copy in all other cases or to republish or to post on a server or to redistribute to lists requires specific permission and payment of a fee. Contact Publisher@InformingScience.org to request redistribution permission. disciplinary approach to IS, one that is neither limited to the locus of the organization nor to the parochial needs of the IS field itself. For instance, the Declaration of Principles and the Plan of Action at the World Summit on the Information Society, held in Geneva in 2003, asserts that the benefits of IT are global and are no longer limited to organizational 
concerns. Conversely, the repercussions of the failures of IS are equally far-reaching. For example, the Federal Bureau of Investigation (FBI), the Central Intelligence Agency (CIA), and the Intelligence Community within the U.S. government blame, among other reasons, ineffective IS for not being able to avert the tragedy of September 11, 2001 (National Commission on Terrorist Attacks, 2004). The repercussions of this IS failure is felt beyond the intelligence community. This paper contends that the IS field needs to widen its focus beyond its traditional foundations in organization studies (OS) by theorizing about its core concern - information technology (IT). Based on a philosophy of technology and a philosophy of information, a framework that embraces societal concerns in studying IT is proposed.

\section{Escaping the Organizational Straightjacket}

The close relationship between IS and organizational studies (OS) is engendered by the OS background of many IS authors. Consequently, IS research is performed hand-inhand with OS research, even though, epistemologically, they are different (Orlikowski \& Barley, 2001). Not only is the field of IS epistemologically different from OS, it is ontologically different from OS. The arguments presented by Orlikowski and Barley (2001) to support the epistemological difference between IS and OS research also support ontological differences between the two fields. In their opinion, because IS studies the development of systems and their consequences, and provides practical solutions to real-life problems, the agenda of IS research closely resembles the agenda of architecture and other design sciences rather than of OS research. OS is closer to traditional science because it provides parsimonious explanations to broad classes of organizational phenomena. As a result, OS discovers generalities, sets down general principles and identifies causal relationships. Therefore, the subject matter (ontology) studied in IS is very different from the subject matter studied in OS. A field that is ontologically and epistemologically different from another cannot hope to flourish if it remains within the constraints of the latter. That is why remaining with OS approaches places the IS field in an "organizational straightjacket." Both the epistemological and ontological differences between IS and OS support the need for a fresh look at how IT should be studied. Additionally, in the limited context of the organization, OS may study "the best way" of managing people in order to improve productivity, whereas IS studies how technology can be designed and implemented to improve organizational productivity. But productivity is not limited to the organization. The field of IS should also be studying how society can be made more productive with the help of technology. Remaining within the bounds of OS prevents the IS field from exploring fertile areas of research outside the organization.

The continued dependence of IS on OS is not always viewed as necessarily a disadvantage. Some IS authors consider remaining within the OS research domain as the duty of IS researchers. For example, in an ICIS 2005 panel of senior IS authors, El-Sawy stressed that IS researchers should focus on improving research and practice in business management and not look at broad societal problems. By improving the practices of the business manager, society will be transformed by the business organization. Galliers disagreed and argued that IS needs to be less parochial and constrained in thinking about its domain in order to make a significant contribution to larger societal problems (Desouza, El Sawy, Galliers, Loebbecke, \& Watson, 2006). The need to expand the focus of IS outside its traditional organizational domain is supported by other studies in the Informing 
Science Journal. Castelao-Lawless and Lawless (2001) highlight the need for students to narrow the gap between the realist pseudo-positivistic view of the science and technology community and the relativistic-modernistic view of the Arts and Humanities. They assert that students who remain on either side of the gap cannot successfully engage their future roles as scientists and policy makers because they lack interdisciplinary practice and are closeted within the two incommensurable epistemologies. Callaos and Callaos (2002) stress the importance of focusing on the nature of information in IS as both objective and subjective and on linking these two roles to create a more comprehensive notion of information that is capable of making significant contributions to the field's stakeholders.

The foundations of IS research should not be restricted to OS because IT is infused into the fabric of society. The impact of IT in one area is immediately felt by other areas. An individual who is "IT literate" not only performs well at work, but becomes instrumental in IT-related tasks performed at the social and political arenas. Unfortunately, research in IS that covers these diverse areas is limited. For example, many studies agree that IT has benefited the U.S. both economically and politically (International Monetary Fund, 2001), but the results of these studies are inconsistent and largely contradictory (Brynjolfsson, 1993; Brynjolfsson \& Hitt, 1998). The "darker side" of IT is largely ignored by IS research. Cases of pedophilia and other computer crimes have skyrocketed because it is becoming more convenient to commit such crimes from the comfort of one's home (New Jersey State Commission of Investigation, 2000). Left unaddressed, these critical issues may create a backlash against the IS field.

\section{The Philosophy of Technology and Informing about IT}

If OS approaches restrict the IS field, where can the field find its new foundations? Because the IS field seeks to inform its customers on the design, use and implementation of IT, one source of inspiration that has rarely caught the attention of IT scholars and practitioners alike - despite its obvious connotations - is the philosophy of technology. In the same way that the philosophy of science answers all philosophical questions arising from reflection on science, the philosophy of technology answers all philosophical questions arising from the reflection on technology. The philosophy of technology, however, arrived later than the philosophy of science. The earliest document to philosophize about technology in its current sense was probably Ernst Kapp's Grundlinien einer Philosophie der Technik (Fundamentals of a Philosophy of Technical Science). Kapp wrote Grundlinien to address the societal problems arising from the use of machines when he was a farmer, carpenter, and stock raiser in Texas. In it, Kapp views mechanical tools and machines, as well as language, science and the state, as projections of human organs or beings (Kapp, 1877).

Even though Kapp wrote Grundlinien before the turn of the $20^{\text {th }}$ century, this view already contradicts the current engineering view of technology as mere tools. Philosophizing and theorizing about technology hold much promise for the IS field that cannot be supported by merely depending on OS-related "reference disciplines." Traditionally, research in IS assumes the engineering view that technology is a tool (Orlikowski \& Iacono, 2001). As a tool, the OS reference disciplines find little need for theorizing IT. IT is treated in IS research as a "black box" that is installed for the goals and objectives set by its designers - to compute, automate or improve a process. Instead, the focus re- 
mains with organizational theories and findings related to them. Several efforts, especially in the 1980s, were undertaken to release the field of IS from this conception of IT (Kling, 1980; Kling \& Scacchi, 1982); however, little progress was realized (Weber, 2003). Unlike this predominant philosophy of IT in the IS field, Kapp's philosophy of technology blurs the distinction between the human element, the environment, and the artifact. Because the artifact is an extension of the human organ, it should no longer be treated as a "black box." Other philosophers such as McLuhan (1964), extending Kapp's views, propose that not only is the modern medium the message (i.e., societies are shaped by the nature of the technological media), but that "the medium is the massage" that works as environments for societies. Not unlike its human creators, every time a new technology is installed, a new environment is created, and as noted by Kapp, enables the human to "continually produce itself." The next sections explore similar insightful interpretations that can be used to chart a direction for the field of IS based on the philosophy of technology.

It is important at this point to distinguish between "information technology" (IT) and "information systems" (IS). It is beyond the scope of this paper to discuss in detail their definitions, but IT is assumed to be the product (the artifact) created by human activity, whereas IS is the field that studies phenomena surrounding IT. A more extensive discussion on this issue may be found in Hassan (2006). One major difference that distinguishes the IS field from other fields of study is its focus on IT. As a field, IS would not have emerged to its present state if not for IT. As many authors have suggested, the general purpose computer is different from previous calculators and industrial machines (Bell, 1973; Higgins \& Glickauf, 1954). The computer is not just a special-purpose accounting machine that is used as a tool. Instead this machine is a general purpose electronic device capable of an unlimited variety of applications and operations, providing infinite possibilities for discourse. This view is opposed to the generally accepted notion that IS existed before computers in the form of manual files. It is the presence of this general purpose electronic device that has raised issues and concerns that are worthy of study (Hassan \& Will, 2006).

\section{An Overview of Different Philosophies of Technology}

Before elaborating on the different philosophies of technology, the term "technology" needs to be clearly defined. Following Ihde (1993), this paper defines technology as something (1) invented, used, designed, or modified by man, (2) that has a concrete component or a material element, and (3) that must be implemented in practice (praxical). This definition summarizes the distinction the Greeks made between physis and poiessis (Feenberg, 1991; Introna, 2002). Physis is what occurs in nature and is understood by the Greeks as that which creates itself. Poiesis is the practical activity in which human beings engage when they produce something. The result of poiêsis is often called an artifact and includes the products of art, craft, and social convention. Automobiles and computers are therefore technologies. But so is writing because it is also invented, it uses artifacts (pen and letters which are both material components) for the purpose of writing, and it is practically implemented, not an academic exercise.

A sports technique designed to improve an athlete's performance or procedures used to reduce inventory are not technologies because there is no concrete component. However, 
if the sports technique is taped, broken down frame by frame to analyze the most efficient form of motion, then, a technology has been employed to perfect a technique. Similarly, if the procedure to reduce inventory holding costs is deployed in an enterprise resource planning system, the procedure (a technique) is technologically implicated, although by itself it is not a technology. Certain interpersonal techniques do not employ technologies - styles of speech, modes of courtship, observation-but become intertwined with technologies if mediated by some IT system. The distinction between technique and technology is summarized in Table 1.

Table 1: Difference between Technique and Technology

\begin{tabular}{|l|l|}
\hline Technique & Technology \\
\hline May exist naturally & $\begin{array}{l}\text { Used, designed, created or modified by } \\
\text { man }\end{array}$ \\
\hline Contains only abstract procedures & Must contain a concrete component \\
\hline $\begin{array}{l}\text { May not be implemented in practice } \\
\text { (academic) }\end{array}$ & $\begin{array}{l}\text { Must be implemented in practice (praxi- } \\
\text { cal) }\end{array}$ \\
\hline
\end{tabular}

This distinction between technique and technology is critical because IS authors often claim that information systems do not necessarily require computers (Davis \& Olson, 1985; Dickson, 1968). This notion, perhaps valid during the time when the field of IS was still closely associated with the accounting field in the 1950s and 1960s, carries the implication that technology does not play a central role in IS research. According to this notion of IS, manual office procedures (techniques) implemented using manual filing systems (a technology) qualify as information systems. However, this definition of IS implicitly views computers (technology) as nothing more than automated filing cabinets deployed to improve the same manual office procedures. Focus is then placed on the techniques rather than on the infinite possibilities offered by such a general purpose electronic technology. Focusing on the techniques discounts the possibility of philosophizing the role of the technology as part of human activity.

Unlike the modern conception of technology, the Greek's understanding of technology as techné (the term that defines the principles involved in producing an object or bringing about an end; technology in the broadest sense) reflects the close relationship technology has with human activity. In Greek tradition, both the existence and the essence of an artifact are created at the same time as it emerges. Each techné contains the essence of the artifact to be made before it is made and is conceived as a response to necessity rather than an independent activity with an ultimate goal (Feenberg, 1991). The common modern conception of technology assumes that the means (the technology) and the ends (the problem to be solved) are independent, and that technology is a neutral instrument, a pure means, based on universal knowledge serving natural needs (hence, the saying "Guns don't kill people, people kill people"). The Greeks instead see human activity as embodied in technology. As Markus (1999) notes, this narrow "instrumentalist" (technology as instruments or tools) approach has caused the field of IS to ignore many important changes overtaking it and has caused the field to fall behind the ever increasing pace of 
technological change. Very few studies give careful consideration to the philosophy of IT beyond this modern instrumental sense (Introna, 2002).

\section{Two Traditional Notions of Technology}

\section{The instrumental theory-Science creates neutral technologies}

The instrumental view of technology is part of the traditional philosophy of technology. The traditional positivistic view of science and technology posits that because the goal of science is the establishment of a value-free objective truth, problems with technology happen only at the applied level. This view assumes that the problems of technology are simply problems of the application of science, not of science per se. This neutral nature of technology suggests that social and environmental impacts of technology are accidental side effects of progress (Feenberg, 1991; Ihde, 1993). In relation to IS research such a view espouses the study of the actions, the decision-making impacts, and cost-benefit measures of the application of the technology rather than a study of the actual technology.

This instrumental view of technology accepts technology as neutral tools, standing ready to serve the purpose of their users. To the field of IS, this view implies that the technology itself is indifferent to the variety of ends it can be employed to achieve. Technology is indifferent to politics and social issues, to the objectives of its users, and its transfer is only limited by costs. It also implies that research relating to technology need only to be rationally verifiable; thus, what works in one organization or society can be expected to work in another. The limitations of this view are clear, especially when applied within an organizational framework. Technology such as IT will be treated somewhat like calculators, as transparent means to the goals of the organization. Research stemming from this approach will tend to focus on the concerns of other disciplines that specialize in social and organizational issues, instead of the new relationships arising from use of IT. Consequently, IS research guided by this view will work to validate or strengthen organization science or management theories instead of building those that the IS field can claim as its own.

\section{The Phenomenological and substantive theory-Technology is not neutral}

The second traditional view of technology comes from the interpretive phenomenological tradition of Husserl (1859-1938) and Heidegger (1977b). Heidegger asserts that ends cannot be separated from the means because technology affects the metaphysical aspect of things by becoming a specific mode of "revealing" (e.g. a hydroelectric dam changes the essence of a river from a producer of water to become a produce of power). Humans as inventors of technology are not outside the technology; instead, human actors are part of the technology. In Heidegger's view, technology, with its magnifying and transforming power, treats the entire world, man included, as "standing reserves," and impose its nihilistic will on man. Consequently technology "enframes" how humans view themselves, and creates a new sense of "being" that makes humans capable of dehumanizing other humans towards their own personal goals. This rather deterministic view of technology is later picked up by Ellul and Marcuse. 
Following Heidegger, Jacques Ellul (1973) and Herbert Marcuse (1964) offer their substantive philosophy of technology. Both philosophers present a pessimistic view of technology constituting a cultural system capable of restructuring the entire world as an object of control. Therefore, using any technology means conforming to it instead of the other way around. The problem is not that technology has taken over people's lives, but that in choosing to use it, people make the unwitting choices that shape their culture and ideology. Political powers, with the help of authoritarian and autonomous technologies, are able to subordinate populations without coercion. Not only is application of technology a kind of domination, technology itself is domination of nature and man. Technology, therefore, is not simply a means or a tool. "Specific purposes and interests of domination are not foisted upon technology 'subsequently' and from the outside; they enter the very construction of the technical apparatus...such a 'purpose' of domination is substantive" (Marcuse, 1968, p. 224). This substantive view of technology carries research on technology to the other extreme and explains the deterministic and dystopian view that formed much of the justification for the Luddite protest of the early 1800s.

The two utopian and dystopian views of technology assume that that technology's impacts are mutually exclusive. The utopian view ignores the ability of technology to be a causal, mediating or moderating factor in affecting changes in society, whereas, the deterministic view of technology ignores the vast potential technology holds towards improving society. In recent years, the utopian view, to a large extent, has overwhelmed the dystopian view. More coverage is given to the benefits of the Internet, the National Information Infrastructure initiated by Al Gore and the Clinton Administration, and later the Health IT program of the Bush Administration, than the ills that IT brings with it. In contrast to these mutually exclusive utopian and dystopian views of technology, several philosophers have attempted to develop a more negotiated and realistic view. They are categorized into critical and phenomenological views of technology.

\section{Critical and Phenomenological Notions of Technology}

\section{Jurgen Habermas's critical view}

Based on the theory of communicative action, Haberrmas (1988) finds a middle ground between the utopian and dystopian views. This alternative approach views the interpretation of social facts as a subjective activity in which "only the meaning intended by the acting subject provides adequate access to behavior performed in a situation that he himself has interpreted" (p. 54). He argues that although technological knowledge implies power, such information is only significant if utilized by the results of technical progress. Habermas (1971) contends that technical development is not autonomous; instead, he regards that technology as socially and politically contingent. Therefore, Habermas disputes Marxian and Marcusian views that technology takes a life of its own in opposition to the interests of its producers. However, he still agrees that technology becomes a universal form of material production, circumscribes an entire culture, and projects a historical totality. In other words, technology has ensured its own cumulative progress, has subordinated traditional structures of legitimization, and has created a world of domination under the guise of modernization. The issue to Habermas (1971) is "how can the power of technical control [technology] be brought within the range of the consensus of acting and transacting citizens?" (p. 57). 


\section{The critical theory of Michael Feenberg}

Feenberg's (1991) critical theory accepts portions of the instrumental view and the substantive view. He accepts the instrumental view that human action is paramount and that civilization is not decided by "the immanent drift of technology" (p. 14). He also accepts the substantive view that technology is non-neutral, but rejects the fatalism of Ellul and Marcuse. Feenberg agrees with Habermas and seeks to explain how technology can be redesigned to the needs of a democratic society. The difference between Feenberg and Habermas is that Feenberg treats technology as a "social battlefield," or "a parliament of things" in which alternatives can be debated and chosen. Because technology is inherently non-neutral, the notion of use of technology is irrelevant because the choice itself has already created a new life-world. So, according to Feenberg any change must be made in the technological sphere itself before it is deployed. For example, one side argues that the computer will eliminate routine tasks and improve our way of life, while the other argues that it puts millions out of work. Critical theory says that technology is neither good nor bad, but can evolve into very different technologies within the framework of domination or democratization. In other words, if more technologies of surveillance and hierarchical control are invented, it is likely that the life-world will be one of domination. Alternatively, if more communicative or "informating" (Zuboff, 1988) technologies are deployed, it is likely a more democratic life-world will evolve.

\section{The of phenomenology of Bachelard, Latour and Foucault- Technology as technoscience}

Drawing from Heidegger's phenomenology and Dewey's “knowing as a technological artifact" view (Hickman, 1990), several philosophers see technology not only as paramount over science, but as a prerequisite for the progress of science. Bachelard (1984, p. 13) first described this kind of inquiry as "phenomeno-technology," a form of phenomenology that is a combination of rationalism and realism. This philosophy rejects the traditional perspective that science is the basis of technology. To explain this concept, Latour (1987, p. 174) coined the term "technoscience" to describe the kind of science that depends on its technological instruments. This "technoscience" perception of technology inverts the relationship between science and technology. Foucault $(1970 ; 1977)$ also supports this perspective and assigns not only power to technology but also attributes the evolution and progress of knowledge to technology. For example, Foucault (1970) credits the microscope for making possible the field of biology because the relationship between organs and their functions that forms the foundation of biology could never have been uncovered without the help of the microscope. The same goes for physics with its instruments and apparatus, or genetics and molecular biology with their electron microscopes. Essentially, according to this view, technology is the origin and cause of science (Ihde, 1979).

The significance of this philosophy to the IS field is that it contradicts the conventional perspective of IS as an applied field. Accepting IS as an applied field implies that basic research will never be its major activity. It also implies that if there is any theory to be tested, it will most likely be one drawn from its many "referent disciplines" instead of one discovered within the field itself. Conceiving IS as a technoscience reverses such limitations because it opens the field to the possibility of autochthonous and original 
theories. It also releases the field of IS from its dependence on its reference disciplines and puts the field at the same standing as physics, biology and other technosciences that have traditionally developed their theories from work in highly technological and instrument-filled laboratories (Latour, 1987).

\section{Ihde's phenomenology of instrumentation and the life-world}

Following up on the concept of the technoscience, Ihde $(1979 ; 1990)$ developed an additional dimension to that conception of technology. A detailed explanation of this approach in the IS field is available in Rathswohl (1991). This approach entails not an impact, but an experience of technology, a form of man-machine phenomenology based on Heidegger's (1977a) philosophy of "things-at-hand." Traditional notions of science and technology accept technology as the effect of applying science, which implies that the solution lies in either the human application or in the conceptual foundation of science itself. By accepting the aforementioned concept of "technoscience," Ihde (1979) is able to argue that the mind (as in science) rises from the body (as in technology). This bodytechnology relationship takes the shape of praxis and an interpretation of technology as a theory of action. It is from embodying praxis that the body-technology becomes concrete. Research in technology can then proceed by examining the human experiences from the embodiment of technology or the immersion of humans in technology. In the same way that a person experiences a blackboard through a piece of chalk, a user experiences his world through technology such as IT. Using this approach, notions such as the level of transparency of the technology, transformation of the user's experience, amplification of experience and knowledge, distance between the user and reality and hermeneutic relations between humans and the real-world can be studied by the IS field.

Table 2: Views of Technology

\begin{tabular}{|l|l|l|}
\hline \multirow{5}{*}{ Traditional Views } & Theory & Description \\
\cline { 2 - 3 } & $\begin{array}{l}\text { Instrumental View } \\
\text { (Ellul, 1973; Heidegger, 1977b; } \\
\text { Marcuse, 1964) }\end{array}$ & $\begin{array}{l}\text { Technology is the means to an } \\
\text { independent set of ends } \\
\text { will dominate society }\end{array}$ \\
\hline \multirow{5}{*}{ Critical Views } & $\begin{array}{l}\text { Social Action Theory } \\
\text { (Habermas, 1971, 1988) }\end{array}$ & $\begin{array}{l}\text { Technology is socially and } \\
\text { politically contingent. It cre- } \\
\text { ates its own structures of le- } \\
\text { gitimization and needs to be } \\
\text { controlled. }\end{array}$ \\
\cline { 2 - 3 } & $\begin{array}{l}\text { Critical Theory (Feenberg, } \\
\text { 1991) }\end{array}$ & $\begin{array}{l}\text { Technology evolves between } \\
\text { domination and democratiza- } \\
\text { tion. Emancipation is possible } \\
\text { only when built into the de- } \\
\text { sign of the technology. }\end{array}$ \\
\hline
\end{tabular}




\begin{tabular}{|l|l|l|}
\hline \multirow{4}{*}{$\begin{array}{l}\text { Phenomenological } \\
\text { views }\end{array}$} & $\begin{array}{l}\text { Technoscience view } \\
\text { (Bachelard, 1984; Foucault, } \\
\text { 1970; Latour, 1987) }\end{array}$ & $\begin{array}{l}\text { Technology is paramount } \\
\text { over science and becomes a } \\
\text { pre-requisite to science }\end{array}$ \\
\cline { 2 - 3 } & $\begin{array}{l}\text { Life-world view (Heidegger, } \\
\text { 1977b; Ihde, 1990, 1993) }\end{array}$ & $\begin{array}{l}\text { Humans experience the world } \\
\text { through an embodiment of } \\
\text { technology }\end{array}$ \\
\hline
\end{tabular}

The critical and phenomenological views present different paradigms for studying IT. Traditional measures of performance related to IT become less relevant. The traditional measures of "use," "satisfaction," "organizational impact," and "adoption" may have been critical during the early years of IS research because organizations were struggling with adoption issues and investments in IT. Today, IT is prevalent and most everyone is left with little choice on whether to use, intend to use or to be satisfied with IT. Instead, measures of effectiveness, literacy, societal impacts, and the digital divide become more pressing issues. All of these issues can be better analyzed using new approaches for studying IT in the IS field. All these conceptions of technology are summarized in Table 2 .

\section{The "Information" in Information Technology and Information Systems}

The next step is to explain how the qualifier "information" in IT describes a specific kind of technology. The most commonly understood theory of "information" is the mathematical information theory of Shannon and Weaver (1949). This theory describes the transmission and communication of information, but not the kind of information that is of interest to IS. As Weaver (Shannon \& Weaver, 1949, p. 8) states:

The word "information," in this theory, is used in a special sense that must not be confused with its ordinary usage. In particular information must not be confused with meaning.

If any theory of information is to inform the IS field, it needs to be one that assumes information contains meaning and, therefore, causes activity in a receiving system simply by virtue of its form. The most useful definition of information for the IS field is the one suggested by Dretske (Mingers, 1996). Dretske defines information as the "propositional content of a signal" (p. 202). This means the signal that is carrying the information necessarily implies a semiotic relationship between the signal and its interpreter. Every sign (signifier) carries meaning concerning something else (signified). This semiotic nature of information has the following implications (Mingers, 1996): (1) the information carried by the signal can be objectified and exists independently from its interpreter (e.g. the images and sounds from a television set are transmitted even if nobody is watching and can be stored and recorded), (2) information must be true to its origin to be information because a signal that deceives is inherently misinforming and is not, therefore, information, (3) the information carried by a signal is distinct from its meaning because information, being a propositional content of the signal, can be infinite whereas the meaning of the signal may be finite (e.g., the signal "the glass of water is on the table" carries a finite 
meaning, but the information that the water is hydrogen and oxygen and boils at 100 degrees Celsius is information "nested" in the signal), and (4) a signal may carry information but may not be meaningful (e.g., when the signs are in a foreign language) or a sign may be meaningful, but carry no information because the information was faulty.

For example, when a person has downloaded a web page and is interacting with its various components, all the information on the page is objective and can be saved as files. Each sign on the web page points to other things, some of it meaningful, others, not. Not all the signs on a web page generate information, depending on its truth value and propositional content. Nevertheless, the structure of meaning that is created between the person and the web page describes a rich semiotic relationship. Not all technological artifacts qualify as IT just because a semiotic relationship exists. Both a calculator and a television generate information and structures of meaning, but are not considered IT. To qualify as IT, an additional condition needs to be specified on the artifact. The artifact needs to be "computer-based." A computer is defined by the Association for Computing Machinery (ACM) as a general-purpose programmable electronic device that uses stored instructions to manipulate symbols (Fritz, 1963). Artifacts that do not include the computer as a component are not considered IT. So a calculator is not IT because it is not general-purpose and is not typically programmable. Gaming technologies, on the other hand, are computer-based, are programmable and clearly create structures of meaning for the interpreter. IT can therefore be defined as a computer-based artifact that generates a structure of meaning for its interpreter.

This capability of information to have meaning distinct from its semantics opens the door to a wider interpretation of information. As an example of this broader interpretation of information, Borgmann (1999) proposes three kinds of information, (1) information about reality, (2) information for reality, and (3) information as reality, all of which may be extracted from the same extensional structure. Borgmann's (1999) conception of information is consistent with Floridi's (2003) philosophy that information is demiurgic, information that could represent or construct reality. The recording and reporting activities performed in IS practice manipulate information about reality. Information developed and communicated in system design and in decision making is information for reality. Music reproduction is an example of information as reality. Within these three approaches to understanding information, many aspects that are not being currently addressed by the IS field can be uncovered. For example, using the approach to information about reality, IS scholars can theorize different kinds of contexts and categories of information that closely describe such reality. The debacle surrounding the misinformation concerning weapons of mass destruction that Iraq allegedly had is an example of $i n-$ formation about reality gone awry. Although it was possible to assess the truth value of this information, based on the credibility of its sources and the coherency of its format, very few people did so. Could the right type of IS have alerted the US intelligence community of the validity of the information it contained? The result of this inability to relate information to its truth value has damaged the reputation of the US intelligence community as well as the reputation of a famous US daily newspaper ("The Times and Iraq", 2004).

An instance of the use of information for reality is the deployment of information in contracts, agreements and laws that organize structures of activity amongst people. Based on 
this conception of information, IS scholars can theorize about the role of information in institutional and societal development. Another example of information for reality is the use of information in the design sciences (Hevner, March, Park, \& Ram, 2004). In October 1996 at the ACM Conference on Object-Oriented Programs, Systems, Languages and Applications (OOPSLA), Christopher Alexander, the famed architect that founded the theory of design patterns was called to give a keynote speech in honor of his work and contribution to computer science and software patterns (Alexander, 1999). Alexander envisioned the critical role that software, because of its ubiquity in design work, construction and planning, could play in fixing the estimated two billion buildings in the world to make them more "whole" and friendly to human life. This challenge of bridging the world of computer science and the world of art and architecture was left unanswered by the computer science field because as a discipline, it is ill-equipped to address such design sciences. Only a field like IS, that recognizes the meaning in this information is capable of bridging this gap. Drawings, charts and guides used in architecture are instances of information for reality or praxis. Systems that are able to provide and enhance such information will be of immense value to society.

The third view of meaningful information is information as reality. Borgmann's (1999) example for this kind of information is music reproduced on CDs. Anyone is able to reproduce reality by playing a music score. The higher the resolution of the message, the less the listener needs to process. Within the context of business functions, the potential for research in information that represent reality, such as virtual reality, simulation, and immersive technologies is virtually limitless. Similarly, research on Internet activities, distance learning, telework and online gaming provides vast areas of productive research for IS scholars. The combination of these views of information can be studied in any particular IT-related context. For example, the power of democratized knowledge used by Internet bloggers to cause Trent Lott, the majority Senate Leader, to resign (Krugman, 2002) should be of interest to IS scholars wanting to discover regimes of power that can be manipulated in public life using merely information about, for, and representing reality.

\section{Information Systems as Technoscience Involving a Structure of Meaning for Its Interpreter}

Floridi stresses the importance of a "unified and cohesive theoretical framework that allows for further specialization" (Floridi, 2002, p. 139). The inclusion of Dretske's philosophy of information with Bachelard's technoscience results in such a philosophy. This philosophy of IT embraces previous research in IS and at the same time opens up the boundaries of the field to novel and unique objects and concepts of study for the field. It recognizes a core that can be accepted by most IS scholars without diluting the specificity and uniqueness of the field - the core of technological information. Table 3 shows the theoretical framework conceptualized from the synthesis of the various philosophies of technology with Borgmann's (1999) views of information. Each cell in the table provides a unique conception or theory of IT. Each conception of IT is made possible by the subjective meaning engendered by the technological information that is contained in the technology (Dretske, 1982). 
Table 3: New Approaches in Studying IT

\begin{tabular}{|l|l|l|l|}
\hline Theory & $\begin{array}{l}\text { Information about } \\
\text { reality }\end{array}$ & $\begin{array}{l}\text { Information for } \\
\text { reality }\end{array}$ & $\begin{array}{l}\text { Information as } \\
\text { reality }\end{array}$ \\
\hline $\begin{array}{l}\text { Instrumental } \\
\text { View }\end{array}$ & $\begin{array}{l}\text { [1] IT as neutral tools } \\
\text { that describe reality }\end{array}$ & $\begin{array}{l}\text { [2] IT as neutral tools } \\
\text { to support the design } \\
\text { of reality }\end{array}$ & $\begin{array}{l}\text { [3] IT as neutral } \\
\text { containers for real- } \\
\text { ity }\end{array}$ \\
\hline $\begin{array}{l}\text { Deterministic/ } \\
\text { Substantive View }\end{array}$ & $\begin{array}{l}\text { [4] IT obscures man- } \\
\text { kind's view of reality }\end{array}$ & $\begin{array}{l}\text { [5] IT dominates re- } \\
\text { ality }\end{array}$ & $\begin{array}{l}\text { [6] IT as dominat- } \\
\text { ing environments }\end{array}$ \\
\hline $\begin{array}{l}\text { Social Action } \\
\text { Theory }\end{array}$ & $\begin{array}{l}\text { [7] Communicative } \\
\text { action to illuminate } \\
\text { reality }\end{array}$ & $\begin{array}{l}\text { [8] Communicative } \\
\text { action to enhance } \\
\text { reality }\end{array}$ & $\begin{array}{l}\text { [9] IT as part of } \\
\text { communicative } \\
\text { action }\end{array}$ \\
\hline $\begin{array}{l}\text { Feenberg's Criti- } \\
\text { cal Theory }\end{array}$ & $\begin{array}{l}\text { [10] Design of IT to } \\
\text { illuminate or obscure } \\
\text { reality }\end{array}$ & $\begin{array}{l}\text { [11] Design of IT to } \\
\text { emancipate or domi- } \\
\text { nate reality }\end{array}$ & $\begin{array}{l}\text { [12] Design of IT } \\
\text { to better represent } \\
\text { reality }\end{array}$ \\
\hline $\begin{array}{l}\text { Technoscience } \\
\text { view }\end{array}$ & $\begin{array}{l}\text { [13] IT making pos- } \\
\text { sible scientific dis- } \\
\text { coveries }\end{array}$ & $\begin{array}{l}\text { [14] IT as making } \\
\text { possible new inven- } \\
\text { tions }\end{array}$ & $\begin{array}{l}\text { [15] IT as tech- } \\
\text { noscience }\end{array}$ \\
\hline Life-world view & $\begin{array}{l}\text { [16] IT as life-world } \\
\text { that illuminates or } \\
\text { obscures reality }\end{array}$ & $\begin{array}{l}\text { [17] IT as life-world } \\
\text { that emancipates or } \\
\text { dominates reality }\end{array}$ & $\begin{array}{l}\text { [18] IT is a life- } \\
\text { world }\end{array}$ \\
\hline
\end{tabular}

To validate the efficacy of these conceptions, each of these eighteen conceptions of IT can be contrasted against Orlikowski and Iacono's (2001) interpretations of IT. Their "IT as Tool," "IT as Computation" and "IT as Absent" views are equivalent to the instrumental view of IT (first row in Table 3). IT makes possible labor substitution, labor augmentation, general increase in productivity and information processing, and changes in social relations (Orlikowski \& Iacono, 2001) because it is through IT that computational work and information processing are performed ([3]--as containers for reality), collaboration and modeling is made possible ([1] IT as neutral tools that describe reality), and social relations and communication behaviors are redesigned ([2] IT as neutral tools to support the design of reality). The key point of the instrumental view is that IT is a neutral enabler that is independent of the goals of its users. Ultimately, the users have full control over IT's enabling capabilities.

Orlikowski and Iacono's (2001) three "proxy" views of IT focus on the subjective interpretations of IT by individuals. Falling in this category is the proxy view of "IT as perception" which includes studies that measure the qualities of IT such as its effectiveness, ease-of-use, and intention-to-use. This view does not escape the instrumentalist interpretation because such studies measure the results of the use of IT as a tool and assumes that substandard performance can be improved by fixing it. The same is the case with the proxy view of "IT as Capital." This view treats IT as an economic resource in the same way as other tools in the organization are treated. The proxy view of "IT as Diffusion" 
overlaps the instrumental view of IT with other non-instrumental views because it involves the integration and penetration of IT in the social context. Although this is partly an issue of use and intention-to-use, it is at the same time also an issue of how IT is capable of dominating the environment (i.e., the substantive view that [5] IT dominates reality).

Orlikowski and Iacono's (2001) "ensemble" view of IT overlaps considerably with the substantive view, social action view, critical theory, technoscience view and life-world view (i.e., approaches [4] through [18]). The ensemble view focuses on the sociotechnical and "web-of-computing" views that do not separate the IT from its context and its related resources. The ensemble view is also the least studied view of IT in the Information Systems Research (ISR) journal (Orlikowski \& Iacono, 2001). The proposed approaches in studying IT expands considerably on the ensemble view by offering fifteen additional theories consistent with it.

\section{Future Research}

The new approaches offer IS researchers many new methods, tools, and research techniques to apply on previous and current issues surrounding IT. For example, IT as part of communicative action approach (approach [9] in Table 3) assumes that the IT is created as a result of certain social and political choices and takes on a "life of its own." In order to uncover the reality of this created environment (approach [7]), researchers can analyze the nature of the IT and perhaps discover reasons for its success or failure based on which instrumental or strategic rules related to it are being complied with or violated. The implementation may be failing because the IT is sufficiently complex (and understandably difficult to implement) to cause certain instrumental rules to be violated. Alternatively, the implementation may be failing because the nature of the IT prompted a conflict of interest within the user group that causes a strategic rule to be violated. A careful diagnosis of the reality taking over the implementation can help stakeholders improve the situation and avoid ultimate failure (approach [8] Communicative action to enhance reality). Traditional IS research on IT success and failure seldom addresses such concerns because it lacks the interpretive and critical approaches needed to perform the above analysis.

Similarly, IT can be designed to obscure reality (approach [10]). Because information essentially consists of "differences that make a difference," IT can be designed to hide information that could make a difference. For example, in 1984 the U.S. Civil Aeronautics Board had to enforce rules to prevent airline carriers from unfavorably displaying their competitor's available seats (termed "display bias") on their airline reservation systems. Alternatively, IT can also be designed to emancipate disadvantaged populations (approach [11]) as is proclaimed by the first world summit of the Information Society (International Telecommunication Union, 2003):

Our challenge is to harness the potential of information and communication technology to promote the development goals of the Millennium Declaration, namely the eradication of extreme poverty and hunger; achievement of universal primary education; promotion of gender equality and empowerment of women; ... for development for the attainment of a more peaceful, just and prosperous world. 
The challenge for the IS research community is to embrace these new approaches that make possible such noble objectives.

\section{Concluding Remarks}

\section{IS Can Be Freed from Its Organizational Straightjacket}

As Orlikowski and Iacono (2001) note, the nominal, tool, proxy and computational views produce the largest number of studies in the ISR journal. All of these views follow the instrumental philosophy of technology. One major implication of the IS field remaining with the instrumental view of IT is to continue limiting much of its research to organizationally-related impact studies. Consequently, as argued in previous sections, IS research remains bounded by its "organizational straitjacket." Remaining with the instrumental approach also implies that the field will neglect substantive impacts of IT. Research in IS will be limited to following technical rules for the purpose of maximizing the efficiency of computer resources in social systems and enhancing the power of technical control. As a result, the field will continue to be subjugated to a multitude of environmental and technological forces, be they organizational bureaucracy or advances in technological development. Although changes in technology are always a welcome justification for research, remaining with the instrumental view will cause the field to become an impoverished account of reality, always years behind in reporting on the latest whiz-bang IT gadget, when it should be a force that shapes reality. The result of this dependence on organizational research has been a tendency for IS researchers to look for theory in organizational science rather than develop their own. Viewing IS as a technoscience implies that IS researchers should worry less about finding and testing theories from its reference disciplines and should focus more on developing theories with IT as a core concern. It is not surprising that the field is currently questioning its own legitimacy (Benbasat \& Zmud, 2003); or in Marcusian terms, slowly becoming "one-dimensional."

\section{As a Technoscience Information Systems Is Not an Applied Field}

The first major implication of the technoscience view of IS contradicts the conventional view of IS as an applied field. The problem with viewing IS as an applied field suggests that IS is dependent on theory and "science" from other fields. By implication, its progress is primarily guided not by the genius or efforts of its own scholars, but by the work of scholars of its "referent disciplines." The "applied" nature of IS also suggests that IS has little to offer other fields. For a field premised on technology such as IS, the division of inquiry into basic and applied research is neither useful nor productive to the field's continuing efforts towards maturity. At its worst, it will impede the progress of the IS field. As Thomas Huxley (1881, p. 155) wrote in 1881:

I often wish this phrase, "applied science," had never been invented. For it suggests that there is a sort of scientific knowledge of direct practice use, which can be studied apart from another sort of scientific knowledge, which is of no practical utility, and which is termed "pure science."

The future of IS should not be found in its role as a pure or applied science, but rather, as a technoscience. Thus it would be able to take advantage of what one of its many core objects of study - technology — has to offer. 


\section{References}

Alexander, C. (1999). The origins of pattern theory: The future of the theory, and the generation of a living world. IEEE Software, September/October, 71-82.

Bachelard, G. (1984). The new scientific spirit [Translation of Le nouvel esprit scientifique 1934]. Boston: Beacon Press.

Bell, D. (1973). The coming of the post-industrial society: A venture in social forecasting. New York: Basic Books.

Benbasat, I., \& Zmud, R. (2003). The identity crisis within the IS discipline: Defining and communicating the discipline's core properties. MIS Quarterly, 27(2), 183-194.

Borgmann, A. (1999). The nature of information at the turn of the millennium. Chicago: University of Chicago Press.

Brynjolfsson, E. (1993). The productivity paradox of information technology. Communications of the $A C M, 36(12), 66-77$.

Brynjolfsson, E., \& Hitt, L. M. (1998). Beyond the productivity paradox: Computers are the catalysts for bigger changes. Communications of the ACM, 41(8), 49-55.

Callaos, N., \& Callaos, B. (2002). Toward a systemic notion of information: Practice consequences. Informing Science Journal, 5(1), 1-11. Available at http://inform.nu/Articles/Vol5/v5n1p001-011.pdf

Castelao-Lawless, T., \& Lawless, W. F. (2001). Informing science (IS) and science and technology studies (STS): The university as decision center (DC) for teaching interdisciplinary research. Informing Science Journal, 4(3), 87-93. Available at http://inform.nu/Articles/Vol4/v4n3p087-093.pdf

Davis, G. B., \& Olson, M. (1985). Management information systems: Conceptual foundations, structure, and development. New York, NY: McGraw-Hill.

Desouza, K. C., El Sawy, O. A., Galliers, R. D., Loebbecke, C., \& Watson, R. T. (2006). Beyond rigor and relevance towards responsibility and reverberation: Information systems research that really matters. Communications of the AIS, 17(16).

Dickson, G. (1968). Management information-decision systems. Business Horizons, 11(6), 17-26.

Dickson, G. W. (1981). Management information systems: Evolution and status. In M. C. Yovits (Ed.), Advances in computers (pp. 1-37). New York: Academic Press.

Dretske, F. I. (1982). Knowledge and flow of information. Cambridge, MA: The MIT Press.

Ellul, J. (1973). The technological society. New York: Alfred A. Knopf.

Feenberg, A. (1991). The critical theory of technology. New York: Oxford University Press.

Floridi, L. (2002). What is the philosophy of information? Metaphilosophy, 33(1/2), 123-145.

Floridi, L. (2003). Two approaches to the philosophy of information. Minds and Machines, 13(4), 459-469.

Foucault, M. (1970). The order of things: An archeology of the human sciences. New York: Pantheon Books.

Foucault, M. (1977). Discipline and punish [Translated from the French by Alan Sheridan]. New York: Vintage Books.

Fritz, W. B. (1963). Selected definitions. Communications of the ACM, 6(4), 152-158.

Galliers, R. D. (2003). Change as crisis or growth? Toward a trans-disciplinary view of information systems as a field of study: A response to Benbasat and Zmud's call for returning to the IT artifact. Journal of the AIS, 4(6), 337-351.

Habermas, J. (1971). Toward a rational society: Student protest, science and politics. Boston: Beacon Press. 
Habermas, J. (1988). On the logic of the social sciences. Cambridge, MA: MIT Press.

Hassan, N. R. (2006). The relationship of IT to IS: An inquiry into the technoscientific nature of the IS field. Paper presented at the Americas Conference on Information Systems, 4-6th August, 2006, Acapulco, Mexico.

Hassan, N. R., \& Will, H. J. (2006). Synthesizing diversity and pluralism in information systems: Forging a unique disciplinary subject matter for the information systems field. Communications of the AIS, 17(7), 152-180.

Heidegger, M. (1977a). Basic writings from being and time to the task of thinking. New York: Harper \& Row.

Heidegger, M. (1977b). The question concerning technology, and other essays. New York: Harper \& Row.

Hevner, A. R., March, S. T., Park, J., \& Ram, S. (2004). Design science in information systems research. MIS Quarterly, 28(1), 75-105.

Hickman, L. A. (1990). John Dewey's pragmatic technology. Bloomington, IN: Indiana University Press.

Higgins, J. A., \& Glickauf, J. S. (1954). Electronics down to earth. Harvard Business Review, 32(2), $97-$ 106.

Huxley, T. H. (1881). Science and culture and other essays (Vol. 3). London: Macmillan.

Ihde, D. (1979). Technics and praxis. Boston: D. Reidel Publishing Company.

Ihde, D. (1990). Technology and the lifeworld. Bloomington, IN: Indiana University Press.

Ihde, D. (1993). Philosophy of technology: An introduction. New York: Paragon House.

International Monetary Fund. (2001). The information technology revolution. Retrieved Nov 2, 2006, from http://www.imf.org/external/pubs/ft/weo/2001/02/index.htm

International Telecommunication Union. (2003). Declaration of principles: Building the information society: A global challenge in the new millennium. Retrieved Apr 24, 2006, from http://www.itu.int/wsis/docs/geneva/official/dop.html

Introna, L. (2002). The question concerning information technology: Thinking with Heidegger on the essence of information technology. In H. J. D. (Ed.), Internet management issues: A global perspective. Hershey, PA: Idea Group Publishing.

Kapp, E. (1877). Grundlinien einer Philosophie der Technik [Foundations of a Philosophy of Technology]. Braunschweig, Germany: G. Westermann.

Kling, R. (1980). Social analyses of computing: Theoretical perspectives in recent empirical research. Computing Surveys, 12(1), 61-110.

Kling, R., \& Scacchi, W. (1982). The web of computing: Computer organizations as social organization. Advances in Computers, 21, 1-90. New York, NY: Academic Press.

Krugman, P. (2002, December 13). The other face. New York Times.

Latour, B. (1987). Science in action. Cambridge, MA: Harvard University Press.

Marcuse, H. (1964). One dimensional man: Studies in the ideology of advanced industrial society. Boston: Beacon Press.

Marcuse, H. (1968). Negations [Translated by J. Shapiro]. London: Penguin Press.

Markus, M. L. (1999). Thinking the unthinkable: What happens if the IS field as we know it goes away? In W. Currie \& B. Galliers (Eds.), Rethinking management information systems. New York: Oxford University Press.

McLuhan, M. (1964). Understanding media. New York: McGrawHill. 
Mingers, J. C. (1996). An evaluation of theories of information with regard to the semantic and pragmatic aspects of information systems. Systems Practice, 9(3), 187-209.

National Commission on Terrorist Attacks. (2004). Law enforcement, counterterrorism, and intelligence collection in the United States prior to 9/11. Retrieved April 25, 2006, from http://www.911 commission.gov/staff statements/staff statement 9.pdf

New Jersey State Commission of Investigation. (2000). Computer crime. Retrieved Nov 2, 2006, from http://csrc.nist.gov/publications/secpubs/computer.pdf

Orlikowski, W. J., \& Barley, S. R. (2001). Technology and institutions: What can research in information technology and research on organizations learn from each other? MIS Quarterly, 25(2), 145-165.

Orlikowski, W. J., \& Iacono, C. S. (2001). Research commentary: Desperately seeking the 'IT' in IT research--A call to theorizing the IT artifact. Information Systems Research, 12(2), 121-134.

Rathswohl, E. J. (1991). Applying Don Ihde's phenomenology of instrumentation as a framework for designing research in information science. In H.-E. Nissen, H. K. Klein \& R. Hirschheim (Eds.), Information systems research: Contemporary approaches and emergent traditions. North-Holland: Elsevier Science Publishers.

The Times and Iraq. (2004, May 26). New York Times, p. A10.

Shannon, C. E., \& Weaver, W. (1949). The mathematical theory of communication. Urbana, IL: University of Illinois Press.

Weber, R. (2003). Editor's comment: Still desperately seeking the IT artifact. MIS Quarterly, 27(2), iii-xi.

Zuboff, S. (1988). In the age of the smart machine: The future of work and power. New York: Basic Books.

\section{Biography}

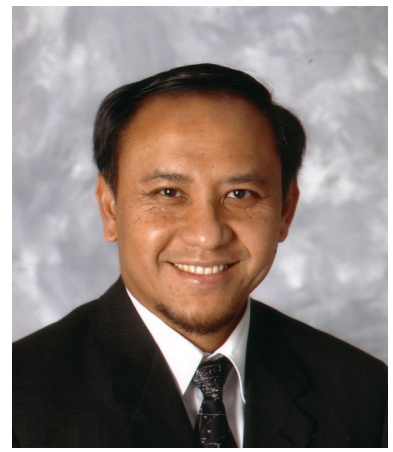

Nik R. Hassan is Assistant Professor at the University of Minnesota Duluth. He received his Bachelors in Actuary from City University, London and his MBA and Ph.D. in Information Systems from the University of North Texas. He served for over 10 years as consultant, government administrator and as senior executive in industry. His current research focuses on improving business process performance, enabling organizational transformation with IT, analyzing "IT literacy," investigating new approaches to systems development and addressing issues of information security. 